\title{
Communication
}

[Comunicação]

\section{Incidence of the second parity syndrome in sows from a commercial farm}

\author{
[Incidência de síndrome do segundo parto em fêmeas suínas de uma granja comercial] \\ S.S. Rabelo, B.G. Faria, L.G.P. Rocha, B.A. Pereira, B.R. Chaves, T.P. Pontelo, \\ L.J. Pereira, M.G. Zangeronimo*
}

Universidade Federal de Lavras - UFLA - Lavras, MG

In recent years, swine production has been undergoing significant transformations. Along with breeding, new challenges are directed to keep high productivity, especially in the areas of nutrition, health, and reproduction.

The main characteristics improved were the higher meat deposition and low fat deposition. At the same time, animals have acquired high reproductive performance, allowing the commercial farms to wean high numbers of piglets. As a consequence of breeding, females come with lower body reserves, which demands larger feed intake during lactation to meet the demand of milk production (Paiva et al., 2006). Moreover, the selection focusing in animals with greater meat deposition resulted in sows with limited consumption capacity (Whittemore and Kyriazakis, 2006). Thus, it is expected that the lactating gilts have catabolic state, resulting in mobilization of tissue due to the high nutrient demand for milk production and lower ovulation rate and embryo survival in the subsequent reproductive cycle, reducing the number of piglets born at second parturition. This drop in productivity between the first and second delivery is known as the second parity syndrome (Patterson et al., 2006).

In most cases, the identification of the second parity syndrome is not detected by some zootechnical indexes such as total number of births or total number of live births. However, the identification of the occurrence of second parity syndrome in commercial farms is important for making decisions that might alleviate this problem, since there is less reproductive efficiency of a group of animals, reducing the economic income from production. Thus, the aim of this study was to evaluate the occurrence of the second parity syndrome in a swine commercial farm and to show alternatives to minimize this reproductive failure.

Data were obtained from a full cycle commercial farm, located in Patos de Minas, Minas Gerais, Brazil. The farm is located at $18^{\circ} 40^{\prime} 59^{\prime}$ ' south latitude and $46^{\circ} 28^{\prime} 06^{\prime}$ ' west longitude, at $815 \mathrm{~m}$ of altitude. The climate is tropical, with mild temperatures in winter $\left(16^{\circ}\right.$ to $\left.21^{\circ} \mathrm{C}\right)$ and warm during summer $\left(23^{\circ} \mathrm{C}\right.$ to $\left.28^{\circ} \mathrm{C}\right)$.

Data from 363 commercial matrices (DB-30) in $1^{\text {st }}$ and $2^{\text {nd }}$ parturition were obtained between 2010 and 2011. Initially, the animals were inseminated in gestation cages $(0.62 \times 2.2 \mathrm{~m})$, where they remained until the $110^{\text {th }}$ day of gestation. For each female, two inseminations with different males were made, following the farm protocol.

The animals were fed with standard diets based on corn and soybean meal. Two weeks prior to the insemination, gilts were fed ad libitum with a flushing diet (3.55 Mcal/kg ME, $19.5 \% \mathrm{CP}$ and $1.3 \%$ of total lysine). Until the $90^{\text {th }}$ day of pregnancy, animals were daily fed with 1.8 to 2.6 $\mathrm{kg}$ of a gestation diet (3.24 Mcal $/ \mathrm{kg} \mathrm{ME}, 15.2 \%$ $\mathrm{CP}$ and $0.8 \%$ of total lysine) and, until weaning, animals were fed with $3.0 \mathrm{~kg}$ of a pre-lactating diet $(3.2 \mathrm{Mcal} / \mathrm{kg} \mathrm{ME}, 17.0 \% \mathrm{CP}$ and $0.9 \%$ of total lysine). During lactation, animals were fed ad libitum with a lactation diet (3.35 Mcal $/ \mathrm{kg}$ ME; $18.0 \% \mathrm{CP}$ and $1.1 \%$ of total lysine). During

Recebido em 4 de agosto de 2015

Aceito em 18 de fevereiro de 2016

* Autor para correspondência (corresponding author)

E-mail: zangeronimo@dmv.ufla.br 
weaning-to-estrus interval, animals were fed with an increasing amount of lactation diet until the $4^{\text {th }}$ day when ad libitum diet was provided. This feed program was elaborated according to company technician recommendations (Shukuri, 2013).

After pregnancy, the females were transferred to the parturition cages $(0.62 \times 2.2 \mathrm{~m})$. The lactation period was $24.6 \pm 3.3$ days. After birth, routine managements were made with piglets: cutting and disinfecting of the navel, cutting teeth, iron and anticoccidial administration. By the $3^{\text {rd }}$ day, the transfer of piglets between the sows was made, seeking litter homogenization by weight and number.

The incidence of second parity syndrome was studied by the total number of born piglets and born live piglets, and the weight of born piglets at birth. The number of weaned piglets and weight and age at weaning were also analyzed. The mean and standard deviation, and the data obtained in the $1^{\text {st }}$ and $2^{\text {nd }}$ parturition were compared by paired $t$ test at 5\%. Statistical analysis was performed using the statistical package Action 2.4.
Considering the total number of matrices, there was no difference in the total number of born piglets $(\mathrm{P}=0.76)$ and the number of live born piglets $(\mathrm{P}=0.89)$ between the $1^{\text {st }}$ and $2^{\text {nd }}$ parturition (Table 1). However, although the average number of born piglets was similar between the $1^{\text {st }}$ and $2^{\text {nd }}$ parturition, we observed that only $46 \%$ (167 in total) of sows had one or more piglets in the $2^{\text {nd }}$ parturition (Fig. 1), while $54 \%$ (196 sows) had equal or fewer piglets at $2^{\text {nd }}$ parturition. In this group of females, there were $3.6 \pm 2.9$ less piglets compared to the $1^{\text {st }}$ parturition. We also observed that $42 \%$ (153 in total) of gilts had 16 or more piglets at $1^{\text {st }}$ parturition. Of these, 60\% (92 gilts) had fewer piglets in $2^{\text {nd }}$ parturition and only $27 \%$ (41 animals) had a bigger litter. In fact, females with high number of piglets in the $1^{\text {st }}$ parturition have more chances of having the second parity syndrome (Segura Correa et al., 2013). Moreover, other factors are also related to this disturbance, such as as body weight at first breeding and weaning, feed programs and nutrition during the first gestation and lactation (Wentz et al., 2010).

Table 1. Reproductive performance of sows in the first and second birth on a commercial farm located in Patos de Minas, Minas Gerais, Brazil, in the years 2010-2011

\begin{tabular}{lccc}
\hline \multicolumn{1}{c}{ Variable } & $1^{\text {st }}$ parturition & $2^{\text {nd }}$ parturition & P value * \\
\hline Number of gilts & 363 & 363 & - \\
Age at breeding (days) & $239.1 \pm 22.3$ & $388.3 \pm 23.8$ & - \\
Weaning-to-estrus interval (days) & - & $6.24 \pm 5.5$ & - \\
Piglets at birth & & & 0.76 \\
Total number & $14.8 \pm 3.1$ & $14.9 \pm 4.0$ & 0.89 \\
Number of live & $13.5 \pm 3.0$ & $13.5 \pm 3.5$ & $<0.01$ \\
Weight (kg) & $1.40 \pm 0.17$ & $1.55 \pm 0.26$ & $<0.01$ \\
Piglets at weaning & & & $<0.01$ \\
Total number & $10.5 \pm 1.6$ & $9.8 \pm 1.7$ & 0.79 \\
Weight (kg) & $6.68 \pm 1.01$ & $6.72 \pm 1.19$ & $24.5 \pm 4.0$ \\
Age (days) & $24.8 \pm 2.8$ & & \\
\hline Value of probability by paired t test. & & & \\
\hline
\end{tabular}

* Value of probability by paired t test. 


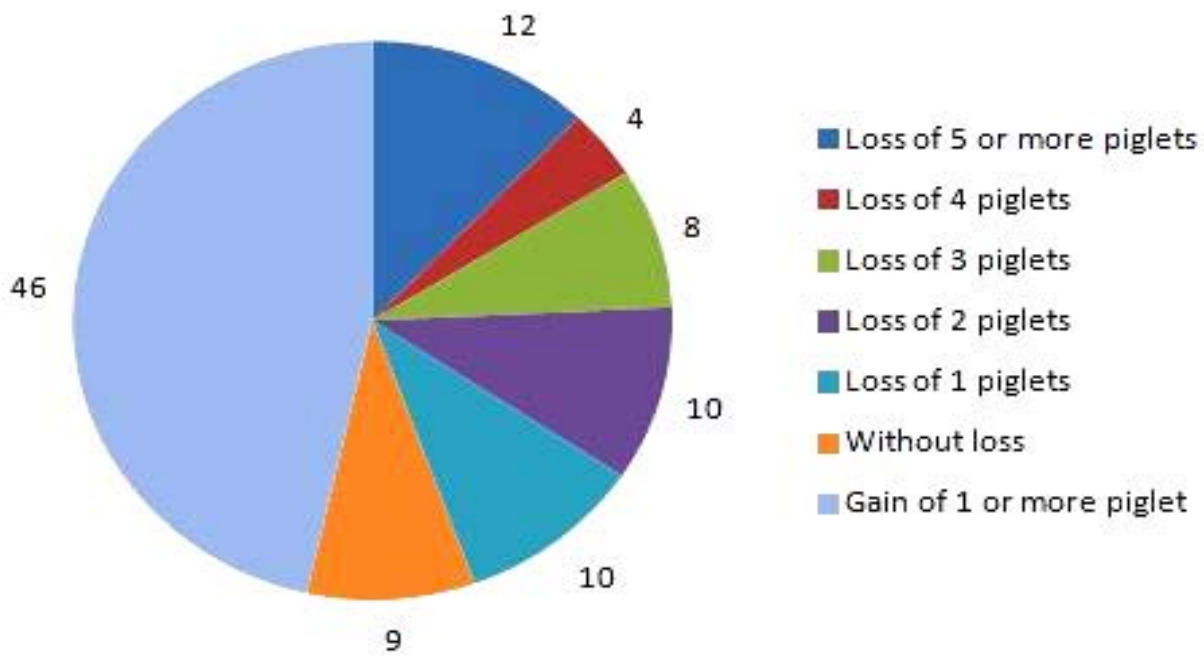

Figure 1. Incidence (\%) of sows that had a lower number of piglets born in the second compared to the first parturition $(\mathrm{n}=363)$.

The body condition of gilts at first insemination has a significant effect on its reproductive life. This occurs because primiparous are still growing and have not yet reached the body mass expected for the mature weight. When the body condition was inadequate, there were low energy and protein reserves necessary to maintain the piglets, resulting in low ovulation rate and small litters on subsequent reproductive cycles (Clowes et al., 2003). According to Williams et al. (2005) the recommended body weight is between 135 and $150 \mathrm{~kg}$ at breeding, regardless of age and back fat level. Moreover, Hoving et al. (2010) also emphasizes that the great variability of daily weight gain of sows is directly related to the incidence of second parity syndrome. In this study, the authors observed that higher weight gain from first insemination to first weaning was associated with higher litter size in second parity. Per $10 \mathrm{~kg}$ higher weight gain from first insemination to first weaning increases with 0.42 piglet in the second parity. In the present study, the weight of females was measured only during the selection and not at breeding. This type of approach contributes to the increased incidence of the second parity syndrome at the farm. Thus, monitoring the body weight of gilts and to increase growth between first insemination and first weaning could optimize the production in second parity.

Nutrition during the first lactation is also an important point. Some studies show that most primiparous suffer lactational catabolism, even fed ad libitum (Pluske et al., 1998). Therefore, inadequate diets during lactation can decrease the ovulation rates in subsequent reproductive cycle and contribute to the second parity syndrome. In the present study, the nutrition during lactation was adequate, following the recommendation of the genetic company.

Another factor that leads to the emergence of the second parity syndrome is the early weaning (less than 20 days, Willis et al., 2003). In this case, the problem would not be the tissue catabolism in females, but the low amount of circulating reproductive hormones, affecting follicle growth and reducing the size of the subsequent litter. Segura Correa et al. (2011) observed that gilts with shorter weaning to conception intervals had higher probability of showing the second-litter syndrome.

All measures to reduce the second parity syndrome occurrence are necessary in a commercial farm, especially in the warmer months of the year. In the present study, the highest incidence ( $50 \%$ or more of gilts) of this syndrome was observed in the months of January to March and October to December (Figure 2). At high temperatures the animals tend to reduce consumption, further aggravating the problem of tissue catabolism during lactation. 


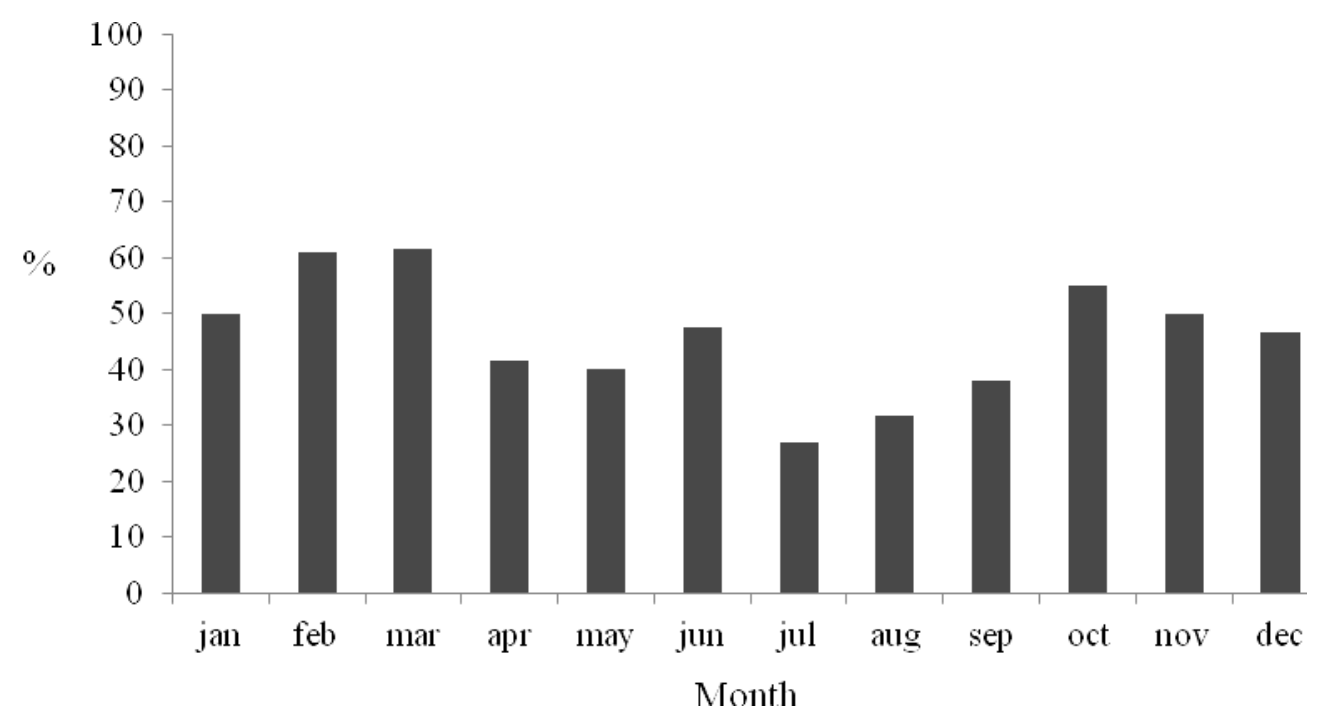

Figure 2. Incidence (\%) of sows that showed reproductive losses in the second parity over the months $(2010-2011)(\mathrm{n}=363)$.

Similar results had been found by Segura Correa et al. (2013) in three commercial farms in Mexico. These authors observed that $55.8 \%$ of all sows presented a reduced or similar litter size at second parity, with higher incidence in sows with large litters at first parity ( $>12$ piglets), especially during high temperature and humidity. These results indicate that the characteristics of second parity syndrome can be similar in different regions of the world.

In conclusion, the second parity syndrome is a problem that can affect $50 \%$ or more of gilts and often cannot be detected by the zoothecnical index of the farm. Sow live weight development seems to have a large influence on reproductive performance in second parity. Thus, measures such as weighing of gilts in the first breeding and immediately after weaning and feed programs with balanced diets mainly during the warmer months of the year are important tools to alleviate the problem caused by low born piglets, especially in farms that adopt early weaning litter.

Keywords: swine, reproductive rates, gilts, primiparous

\section{RESUMO}

O objetivo do presente estudo foi investigar a ocorrência da síndrome do segundo parto em uma granja comercial de suínos e apresentar alternativas para minimizar esse problema reprodutivo. Os dados foram obtidos de 363 fêmeas de genética comercial (DB-30) de primeiro e segundo partos, entre os anos de 2010 e 2011. Os animais pertenciam a uma granja comercial de ciclo completo com 1200 matrizes, cujos índices zootécnicos não permitiam detectar a presença da síndrome do segundo parto. O período de lactação foi de 24,6士3,3 dias. Foram analisados o número de nascidos totais e nascidos vivos, o peso da leitegada ao nascimento, o número de desmamados e o peso ao desmame do lote e também individualmente de cada marrã ao longo do ano. As médias e o desvio-padrão foram calculados, e os dados obtidos no primeiro e no segundo parto foram comparados pelo teste t pareado a 5\%. Não houve diferença $(P>0,05)$ no número de nascidos totais e no número de nascidos vivos entre o primeiro e o segundo parto. No entanto, constatou-se que 54\% das fêmeas apresentaram igual ou menor número de nascidos no segundo parto, caracterizando a síndrome do segundo parto na maior parte dos animais. Nesse lote, o número de leitões nascidos a menos em relação ao primeiro ciclo reprodutivo foi de 3,6士2,9. Das 363 matrizes avaliadas, 153 (42\%) apresentaram 16 ou mais leitões no primeiro parto. Destas, 92 (60\%) tiveram menor número de leitões no segundo parto e 41 (27\%) apresentaram maior 
número de leitões. Também se verificou maior incidência (50\% ou mais) da síndrome do segundo parto nos meses de janeiro a março e de outubro a dezembro. Conclui-se que a síndrome do segundo parto é um problema que pode afetar 50\% ou mais das matrizes, nem sempre detectada por meio dos índices zootécnicos da granja. Medidas como pesagem dos animais na primeira cobertura e logo após o desmame, além de programas de alimentação com dietas balanceadas, principalmente durante os meses mais quentes do ano, são ferramentas importantes para amenizar esse problema.

Palavras-chave: suinocultura, índices reprodutivos, marrãs, primíparas

\section{ACKNOWLEDGMENT}

The authors thank FAPEMIG, CAPES, CNPq and the Graduate Program in Veterinary Sciences, Federal University of Lavras, for financial support.

\section{REFERENCES}

CLOWES, E.J.; AHERNE, F.X.; SCHAEFER, A.L. et al. Parturition body size and body protein loss during lactation influence performance during lactation and ovarian function at weaning in first-parity sows. J. Anim. Sci., v.81, p.15171528, 2003.

HOVING, L.L.; SOEDE, N.M.; GRAAT, E.A.M. et al. Effect of live weight development and reproduction in first parity on reproductive performance of second parity sows. Anim. Reprod. Sci., v.122, p.82-89, 2010.

PAIVA, F.P.; DONZELE, J.L.; OLIVEIRA, R.F.M. et al. Energia digestível em rações para porcas primíparas em lactação. Arq. Bras. Med. Vet. Zootec., v.58, p.234-241, 2006.

PATTERSON, J.; ZIMMERMAN, P.; DYCK, M. et al. Effect of skip-a-heat breeding on subsequent reproductive performance in 1 st parity sows. Adv. Pork Prod., v.17, p.24, 2006.
PLUSKE, J.R.; WILLIAMS, I.H.; ZAK, L.J. et al. Feeding lactating primiparous sows to establish three divergent metabolic states: III. milk production and pig growth. J. Anim. Sci., v.76, p.1165-1171, 1998.

SEGURA CORREA, J.C.; ALZINA-LÓPEZ, A.A.; SANTOS-RICALDE, R.H. Risk factors associated with the occurrence of the secondlitter syndrome in sows in southeastern Mexico. Sci. World J., v.2013, p.1-4, 2013.

SHUKURI, G. Manejo de fêmeas de reposição. 2.ed. Pato de Minas: DB Genética Suína, 2013. 46p.

WENTZ, I.; WERLANG, R.F.; BORTOLOZZO, F.P. Como abordar o problema da síndrome do segundo parto. Acta. Sci. Vet., v.38, Supl.1, p.s121-s133, 2010.

WHITTEMORE, C.T.; KYRIAZAKIS I. Whittemore's science and practice of pig production. 3.ed. Oxford: Blackwell Publishing, 2006. 704p.

WILLIAMS, N.H.; PATTERSON, J.; FOXCROFT, G.R. Non-negotiables in gilt development. Adv. Pork Prod., v.16, p.281-289, 2005.

WILLIS, H.J; ZAK, L.J.; FOXCROFT, G.R. Duration of lactation, endocrine and metabolic state, and fertility of primiparous sows. J. Anim. Sci., v.81, p.2088-2102, 2003. 